\title{
パルスセロダイン変調を用いたパルス光の瞬時周波数制御
}

\author{
原口英介, 尾野仁深, 安藤俊行 \\ 三菱電機株式会社（２427-8501 神奈川県鎌倉市大船5-1-1)
}

\section{Instantaneous Frequency Control within a Single Pulse Period Using Pulsed Serrodyne Modulation}

\author{
Eisuke HARAGUCHI, Hitomi ONO, and Toshiyuki ANDO \\ Mitsubishi Electric Corporation, 5-1-1 Ofuna, Kamakura, Kanagawa 247-8501
}

(Received July 19, 2017)

\begin{abstract}
We developed a new pulsed-coherent light source for wind sensing by combining a semiconductor optical amplifier (SOA) with a phase modulator that was operated to produce pulsed serrodyne modulation. Even though an SOA-based light source has the potential advantages of a small footprint, monolithic integration, and gain properties, instantaneous frequency deviation inevitably occurs, leading to measurement errors of wind velocity. We demonstrated the correction of such frequency deviation using phase modulation with a pulsed sawtooth waveform and clearly demonstrated that the instantaneous frequency deviation was compensated sufficiently to achieve residual frequency errors of $0.4 \mathrm{MHz}$, compared to $40 \mathrm{MHz}$ without correction.
\end{abstract}

Key Words: Serrodyne Modulation, SOA, Laser Imaging Detection and Ranging (LIDAR), Instantaneous frequency control

1. はじめに

コヒーレントドップラライダ (Coherent Doppler LIDAR: CDL) は単一周波数のレーザー光を空間照射し, 観測空 間内を移動するエアロゾルをトレーサとし，その散乱光 周波数のドップラシフトから風速を計測する装置であ る。これまで多くのCDLに関する研究がなされており, 国際標準化活動も行われている ${ }^{1-7)}$. 特に波長 $1.5 \mu \mathrm{m}$ の 光源と光ファイバ部品により構成した全光ファイバ型 CDLはアイセーフ, 小型，高信頼のシステムを実現でき る利点がある ${ }^{4-7)}$ 。近年では，風車の高効率化を目的と して，風車のナセル上にCDLを搭載する試みが行われて おり, さらなる小型化・可搬可能な構成が望まれてい $3^{8,9)}$. 我々はさらなる小型化に向け, 半導体光増幅器 (Semiconductor Optical Amplifier: SOA)を用いたCDL光送 受信部についての検討を行っている.SOAは小型, 集積 化に加えて利得補填や強度変調が可能といった利点があ

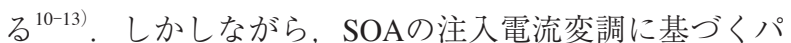
ルス変調を行う場合, 内部の屈折率の変動に伴い, パル スON期間に瞬時的な周波数偏移が生じることが知られ ている ${ }^{12,13)}$ 。この瞬時周波数偏移量はパルス波形や, 出 力光強度に依存し，CDLに使用するロングパルス (100-1000 ns領域) では15-150 MHz程度と見込まれ る ${ }^{12)}$. CDLにおいて, この周波数偏移量は風速誤 差10-100 m/sに相当し，無視できない。これまで我々は CDLに使用される光ファイバ内での自己位相変調 (Self
Phase Modulation: SPM)により生じるパルス ON期間内の 周波数偏移の平均值を信号処理にてオフセット減算する ことで, 補正可能であることを実証した ${ }^{14)}$. しかし，SOA内 で発生する周波数偏移量はCDL受信带域 $( \pm 50 \mathrm{MHz})$ よ り大きいと推察される為, 受信後のオフセッ補正は適用 困難である ${ }^{4)}$ 。我々は，SOAを用いた小型風計測ライダの 実現に向け，パルスセロダイン変調によるパルスON期間の 瞬時周波数の制御法を考案した，本論では，本方式を用 いた瞬時周波数偏移補償の実証結果について報告する.

\section{2. パルスセロダイン変調を用いた光送受信部}

ここでは，パルスセロダイン変調を用いたCDL光送受 信部の構成, フリーラン時の瞬時周波数偏移量評価, 及 びパルスセロダイン変調を用いた瞬時周波数偏移補償方 法に関する検討結果について述べる.

\section{1 光送受信部基本構成}

Fig. 1 にパルスセロダイン変調を用いた光送受信部構 成図を，Fig. 2 に試作した信号処理部 (SP) を含む光送受 信ボードの外観を示す。基準光源 (Master Laser) 出力光 を送信光路 $(\mathrm{Sig})$ と局発光路 (Local) に2分岐する。送信 光路では, 光周波数シフトを実現する光位相変調器 (LNM), 送信光をパルス化する半導体光増幅器 (SOA) を介して出力する. 出力された送信光は光増幅器 (OHPA) にて増幅後, 送受光路分離用の偏波保持サー 


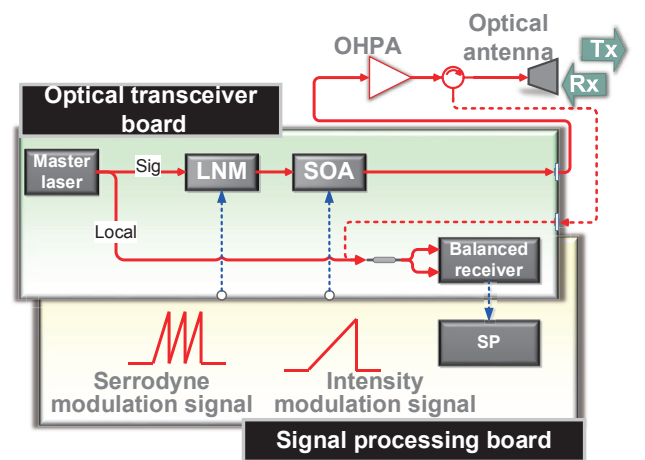

Fig. 1 Configuration of the optical transmitter using pulsed serrodyne modulation.

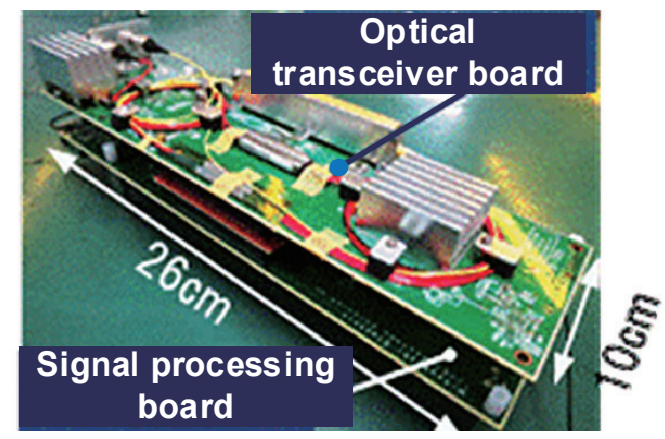

Fig. 2 Outer view of the new coherent Doppler LIDAR engine.

キュレータを介して, 光アンテナ (Optical Antenna)にて 空間出力される $(\mathrm{Tx})$. エアロゾルからの散乱光 $(\mathrm{Rx})$ を 光アンテナで受信し，偏波保持サーキュレータで送受分 離後, 光送受信部の受信ポートに入力する. 受信光と局 発光とを合波後, バランストレシーバ(Balanced Receiver) にて受信し, 信号処理部 (SP)で時間・周波数解析を行う.

Fig. 3 に各種変調信号イメージ図を示す。パルスセロ ダイン変調では, 繰り返し周期 (PRI)のパルスON期間 $\left(T_{1}\right)$ にのみ鋸波状の変調信号を光位相変調器に印加し, パルスOFF期間には変調信号をOFFとする. 位相の変化 量 $(d \phi / d t)$ と周波数 $(\Delta f)$ には $\Delta f=1 / 2 \pi \times d \phi / d t$ の関係が成り 立つ為, 一定周期 $\left(T_{\mathrm{m}}\right)$, 変調幅 $2 \pi$ の位相変調を印加した 際， $1 / T_{\mathrm{m}}$ の周波数がシフトされる. 以上を踏まえるとパ ルスON期間とOFF期間の送信光電場 $\left(E_{\mathrm{S}_{\mathrm{OON}},} E_{\mathrm{S}_{\mathrm{OOFF}}}\right)$, 及 び局発光電場 $\left(E_{\mathrm{L}}\right)$ はそれぞれ次式で表される。ここで $E_{\mathrm{S}}$, $E_{\mathrm{L}}$ は送信光, 局発光の振幅, $f_{0}$ は基準光源の光周波数, $T_{\mathrm{m}}$ は鋸波の周期を表す。

$$
\begin{aligned}
& E_{\mathrm{S} \_ \text {ON }}=E_{\mathrm{S}} \exp \left[i\left\{2 \pi\left(f_{0}+\frac{1}{T_{\mathrm{m}}}\right) t+\phi_{\mathrm{S}}\right\}\right] \\
& E_{\mathrm{S} \_ \text {OFF }}=E_{\mathrm{S}} \exp \left[i\left\{2 \pi f_{0} t+\phi_{\mathrm{S}}\right\}\right] \\
& E_{\mathrm{L}}=E_{\mathrm{L}} \exp \left[i\left\{2 \pi f_{0} t+\phi_{\mathrm{L}}\right\}\right]
\end{aligned}
$$

上式を用いて，バランスとレシーバの光電変換効率を $\eta, \Delta \phi$ を信号光と局発光の光位相差とすると, パルス ON，OFF期間に出力した送信光の受信信号はそれぞれ 式(2)，（3）で表される。ここで，風計測に用いる受信信 号は夕ーゲットまでの遅延時間が生じる為, パルス OFF

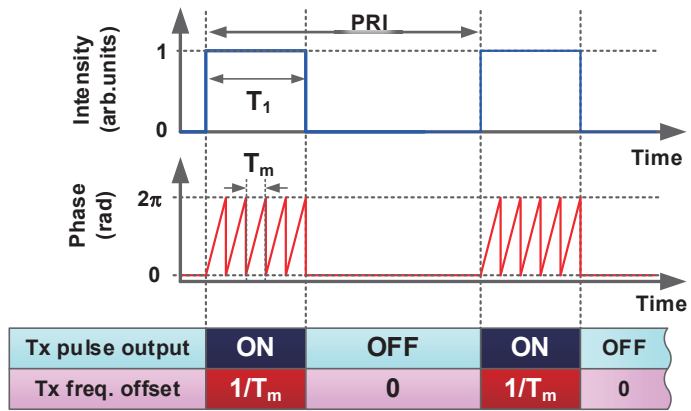

Fig. 3 Temporal signal of pulsed serrodyne modulation for an optical phase modulator and the SOA.

期間に受信することになる。式(2)より，パルスON期間 に出力し，パルスOFF期間に受信した信号は周波数 1 / $T_{\mathrm{m}}$ のビート信号が検出されるのに対し，パルス $\mathrm{OFF}$ 期間 に出力した送信光のパルスOFF期間に受信した信号は (式(3))DC成分のみとなることがわかる.

$$
\begin{gathered}
I_{\mathrm{S}_{\mathrm{ONN}}}=\eta\left|E_{\mathrm{S} \_ \text {ON }}-E_{\mathrm{L}}\right|^{2} \\
=\eta\left|E_{\mathrm{S}}\right|^{2}+\eta\left|E_{\mathrm{L}}\right|^{2} \\
+2 \eta E_{\mathrm{S}} E_{\mathrm{L}} \sin \left(\frac{2 \pi t}{T_{\mathrm{m}}+\Delta \phi}\right) \\
I_{\mathrm{S}_{\mathrm{OOFF}}}=\eta\left|E_{\mathrm{S} \_ \text {OFF }}-E_{\mathrm{L}}\right|^{2} \\
=\eta\left|E_{\mathrm{S}}\right|^{2}+\eta\left|E_{\mathrm{L}}\right|^{2}+2 \eta E_{\mathrm{S}} E_{\mathrm{L}} \sin (\Delta \phi)
\end{gathered}
$$

\section{2 瞬時周波数偏移量評価}

本節では，新規構成を用いたSOAの注入電流直接変 調, 及び光ファイバ増幅器 (Erbium Doped optical Fiber Amplifier: EDFA) 出力後の光ファイバ内で生じるSPMに よる瞬時周波数偏移量評価結果について述べる.

Fig. 4 に評価系構成図を示す。基準光源には中心波 長1550.12 nm, 縦モード線幅200 kHzのDFB-LDを用い た，LNM，SOAによりパルスセロダイン変調されたパル ス送信光をEDFAにて増幅後, 光アッテネータ (ATT)で 減衰, 光サーキュレータ $(\mathrm{CIR})$ にて送受信光路を分離 し，500 mの遅延ファイバを伝播させる $(\mathrm{Tx})$. 遅延ファ イバ伝播先の光コネクタ $(\mathrm{FE})$ をオープンとし, 端面反 射による反射光を受信光 $(\mathrm{Rx})$ とする．受信光は光サー

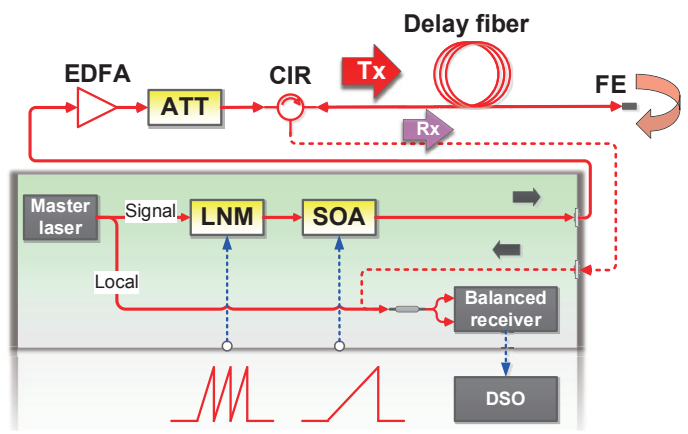

Fig. 4 Schematic block diagram of experimental setup for estimation of instantaneous frequency deviation caused by direct modulation of the SOA and SPM. 
キュレータで受信光路に分離され, 光送受信部の受信 ポートに入力する. 受信信号はオシロスコープ(Digital Sampling Oscilloscope: DSO)にて測定し，ゲート時間を 変化させながらFFTを行うことで, パルス内の周波数 チャープ量を見積もる。本評価では, セロダイン変調周 波数を $160 \mathrm{MHz}$ (立下り時間 : $0.1 \mathrm{~ns}$ ), $\mathrm{SOA}$ はパス 幅400 ns (CDLでの距離分解能60 m) のランプ波形, 繰り

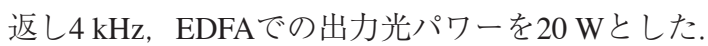

受信信号時間波形，及びFFT結果の一例としてゲート 位置を2 $\mu \mathrm{s}$ (Gate2：パルスOFF期間送信光受信領域), $5 \mu \mathrm{s}$ (Gate1：パルスON期間送信光受信領域)とした場合 のスペクトラムをFig. 5 に示す。眓より, 遅延ファイバ 長 $500 \mathrm{~m}$ (光路長750 m)のダブルパスに相当する $5 \mu \mathrm{s}$ 付近 (Gate1)にビート信号が検出されているのに対し，パル スOFF期間送信光を受信したGate2(ゲート位置 : $2 \mu \mathrm{s}$ )で はビート信号が検出されていないことがわかる。また, FFT結果より，ビート信号の中心周波数がSOA注入電流 直接変調，及びSPMによる瞬時周波数偏移の影響によ り，変調周波数の $160 \mathrm{MHz}$ から+側に偏移していること が読み取れる。

この周波数偏移は式(4)に示すようにSOA注入電流直 接変調により生じる周波数偏移 $\left(f_{\text {chirp_SOA }}\right)$ と $\left.^{12}\right), \mathrm{SPM} に$ る周波数偏移 $\left(f_{\text {chirp_SPM }}\right)$ であらわされる ${ }^{14)}$. ここで, $U(T)$ は光パルスの光電場を, $\alpha$ は振幅・位相結合係数を, $L$ は 実効的ファイバ長を， $L_{\mathrm{NL}}$ は非線形ファイバ長を表す.

$$
\begin{aligned}
& f_{\text {chirp }}=f_{\text {chirp_SOA }}+f_{\text {chirp_SPM }} \\
& =\frac{\alpha}{4 \pi} \frac{1}{|U(T)|^{2}} \frac{\partial}{\partial T}|U(T)|^{2}-\frac{1}{2 \pi}\left(\frac{L}{L_{\mathrm{NL}}}\right) \frac{\partial}{\partial T}|U(T)|^{2}
\end{aligned}
$$

上式において，第1項がSOAの注入電流直接変調により 生じる瞬時的な周波数偏移を，第2項がSPMにより生じ る瞬時的な周波数偏移を表す。Gate1付近におけるビー ト信号スペクトル中心周波数の瞬時的な変動と, SOA,

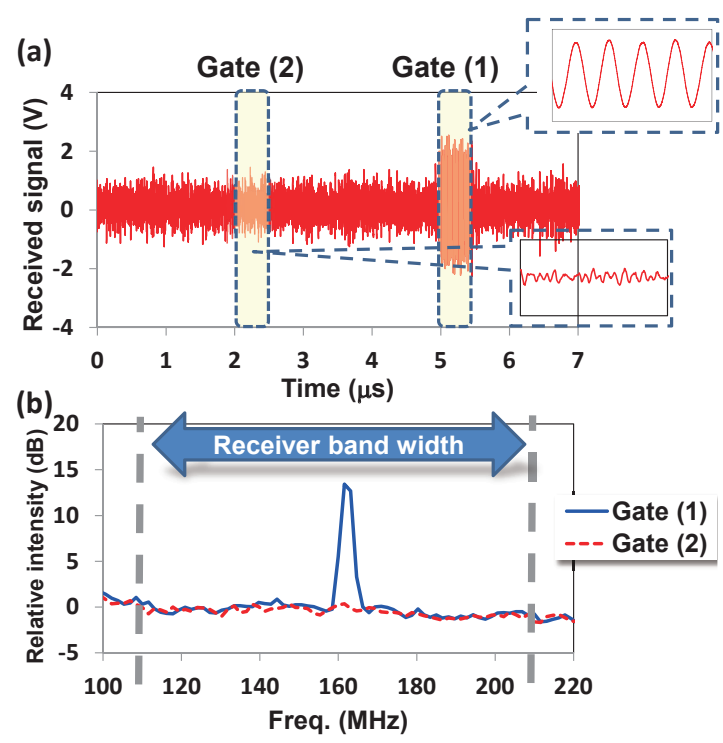

Fig. 5 Heterodyne signal between local and back-reflected light (a) Time domain data, (b) Spectrum. (a)

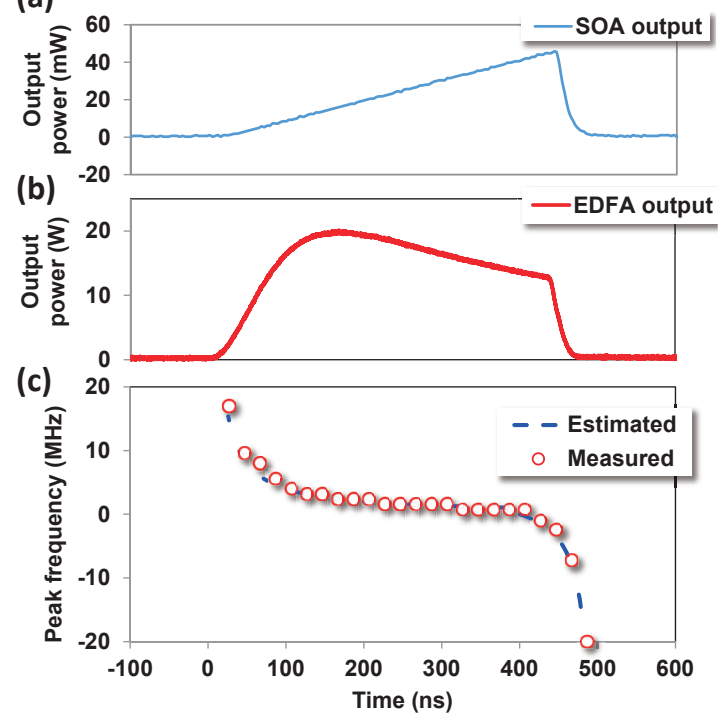

Fig. 6 Optical transmitting pulse shape (a), (b) and instantaneous frequency deviation (c).

EDFA出力光パルス波形, 及び式(4)に実測したパルス 波形を適用した瞬時周波数の解析結果をFig. 6 に併せて 示す。解析において, 式(4)第1項のパルス波形には Fig. 6(a)のSOA出力光パルス波形を, 式(4)第2項には Fig. 6(b) のEDFA出力波形を用い, 各種パラメータは $\alpha: 5, L_{\mathrm{NL}}: 44 \mathrm{~m}, L: 24 \mathrm{~m}$ とした ${ }^{12,14)}$. 図より解析結果 と実測結果とが良好に一致し, パルス立ち上がり領域では正 の周波数偏移が, パルス立下り領域では負の周波数偏移 が20 MHz程 (風速 $15.5 \mathrm{~m} / \mathrm{s}$ 相当)生じていることがわかる.

\section{3 周波数偏移補償原理}

ここでは, CDL光送信部で生じる瞬時周波数偏移のパ ルスセロダイン変調を用いた補償原理について述べる.

Fig. 7 に周波数偏移補償原理図を示す。2.1節で述べたよ うにパルスセロダイン変調による周波数シフト量は鋸波 周期によって決まる。この鋸波周期を時間的に変化させ ることで，パルス ON期間内の瞬時周波数制御を行う. 印加する瞬時周波数には式(4)であらわされるCDL光送 信部に生じる瞬時周波数偏移特性 $\left(f_{\text {chirp }}(t)\right)$ の逆特性に才 フセット周波数 $f_{\mathrm{m} 0}$ を加算したものを与える。これによ りパルスON期間に生じる瞬時周波数偏移の補償し, 且 つCDLで要求される周波数シフトを付加したパルス光を 生成する。

$$
\begin{aligned}
& E_{\mathrm{S} \_\mathrm{ON}}(t)=E_{\mathrm{S}} \exp \left\lfloor i 2 \pi\left(f_{0}+f_{\mathrm{m}}(t)+f_{\text {chirp }}(t)\right) t\right\rfloor \\
& f_{\mathrm{m}}(t)=f_{\mathrm{m} 0}-f_{\text {chirp }}(t)
\end{aligned}
$$

ここで, 従来CDL光送信部に用いられてきたAOM (Acousto Optical Modulator) は変調可能な周波数幅が 数 $\mathrm{MHz}$ ，変調帯域が10 MHzほどであり，パルスON期 間に生じる瞬時周波数偏移を補償するには帯域，変調幅 ともに不足している。一方, 本方式で用いる光位相変調 器は変調帯域, 変調幅ともに数 GHz以上と広帯域であ るため, 数 nsのパルス幅であっても適用可能である. 
$\begin{array}{ll}\text { (a) : Without correction } & \text { (b) : With correction }\end{array}$ Phase mod. signal
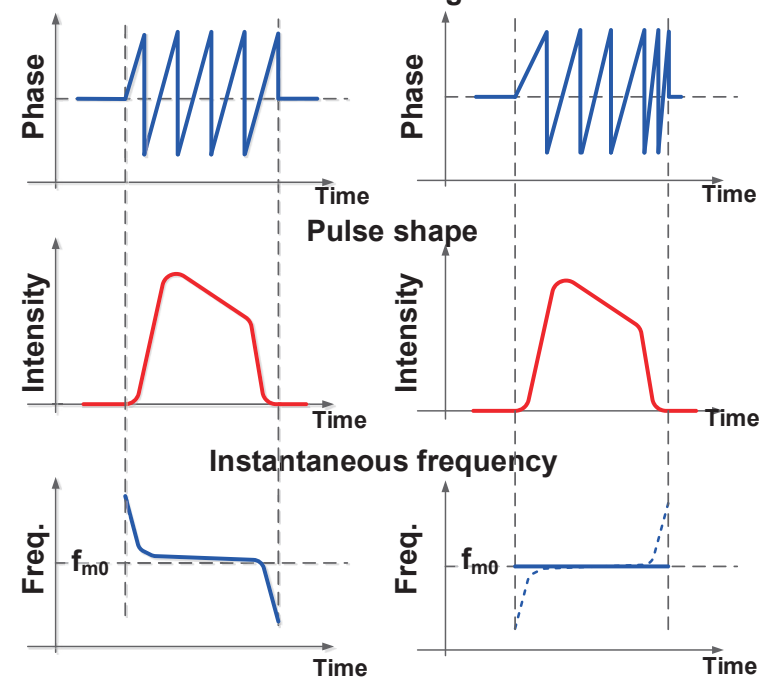

Fig. 7 Temporal signal of pulse serrodyne modulation without correction (a) and with correction (b).

\section{3. パルスセロダイン変調による瞬時周波数偏移補償}

本章では, 瞬時周波数偏移補償実験結果について述べ る。実験に用いた瞬時周波数の中心周波数 $160 \mathrm{MHz}$ から の変化量をFig. 8 に示す. 評価にはFig. 4 に示す評価系 を用いた。2.2節で評価した周波数偏移の逆特性をもつ

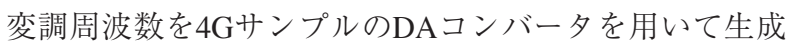
乙 (時間分解能 $d t=10 \mathrm{~ns}(\mathrm{a}), d t=1 \mathrm{~ns}(\mathrm{~b})$ ), 瞬時周波数 偏移評価を行った。

評価結果をFig. 9 に示す。図より, 時間分解能10 nsの 補償信号を印加した際(Fig. 9(a)) は, パルス立ち上が り, 立下り領域における周波数偏移を補償しているもの の, 最大 $\pm 4.2 \mathrm{MHz}$, 平均 $1.5 \mathrm{MHz}$ の周波数偏移が残存し ている。一方, 時間分解能1 nsの補償信号を印加した際 には (Fig. 9(b))，フリーラン時 $\pm 20 \mathrm{MHz}$ の周波数偏移が パルス内全領域において一定となっていることがわか る.このとき残存周波数偏移量は最大 $\pm 0.4 \mathrm{MHz}$, 平 均 $0.03 \mathrm{MHz}$ (風速換算 $0.02 \mathrm{~m} / \mathrm{s}$ ) と CDL受信帯域と比べ十 分小さい值であった。これは, SPMによる周波数偏移量 である数 MHz以下であり，信号処理部におけるオフ セット減算により補正可能である ${ }^{14)}$.

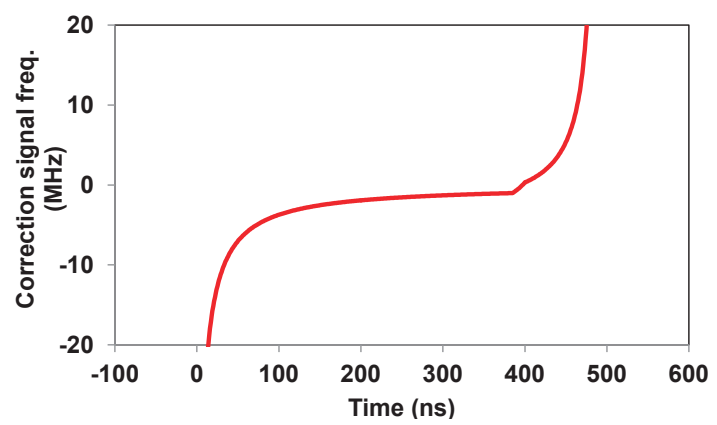

Fig. 8 The frequency of serrodyne modulation. (a)
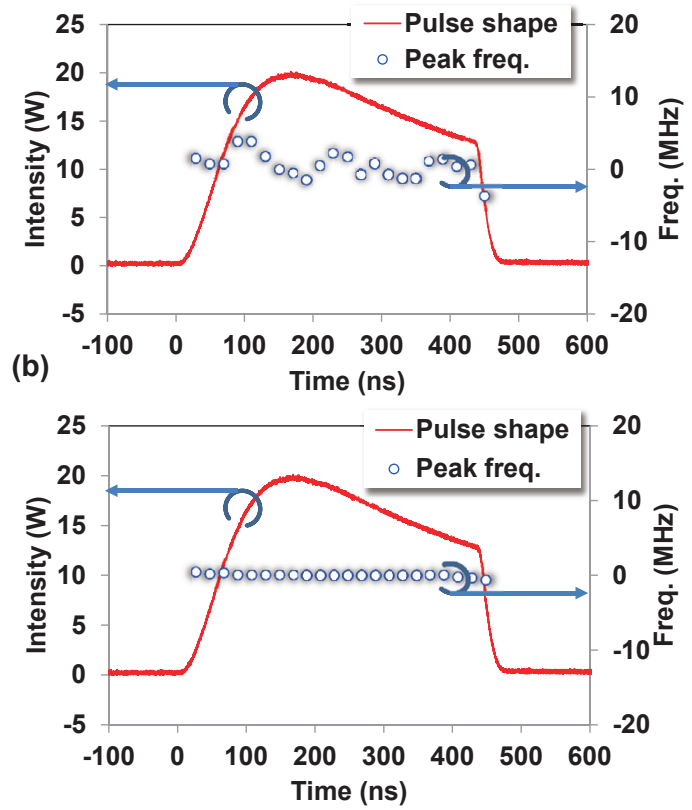

Fig. 9 The peak frequency of heterodyne beat signals with correction (a) dt $=10 \mathrm{~ns}$ and (b) $\mathrm{dt}=1 \mathrm{~ns}$.

4. まとめ

本研究では, CDL送受信部へのSOA適用に向け，パル スセロダイン変調を用いたパルス内周波数偏移補償方式 を提案し，評価実証を行った。その結果，パルス 幅400 nsのパルス光に対し補償前に生じていた最 大 $40 \mathrm{MHz}$ の周波数偏移を $0.4 \mathrm{MHz}$ 以下まで抑圧し，提案 方式の効果を実証した。残存する周波数偏移量はCDL受 信帯域幅と比べ十分小さく，信号処理によるオフセット 減算にて処理可能である。

\section{参考文献}

1) R. M. Huffaker and R. M. Hardesty: Proc. IEEE 84 (1996) p. 181

2) J. M. Vaughhan, K. O. Steinball, C. Werner, and P. H. Flamant: Proc. IEEE 84 (1996) p. 205.

3) ISO/PRF 28902-2.

4) S. Kameyama, T. Ando, K. Asaka, Y. Hirano, and S. Wadaka: Appl. Opt. 46 (2007) 1953.

5) C. J. Karlsson, F. A. A. Olsson, D. Letalick, and M. Harris: Appl. Opt. 39 (2000) 3716.

6) G. N. Pearson, P. J. Roberts, J. R. Eacock, and M. Harris: Appl. Opt. 41 (2002) 6442.

7) A. Dolfi-Bouteyre, G. Canat, M. Valla, B. Aug'ere, C. Besson, D. Goular, L. Lombard, J. Cariou, A. Durecu, D. Fleury, et al.: IEEE J. Sel. Top. Quantum Electron. 15 (2009) 441.

8) D. Schlipf, P. Fleming, F. Haizmann, A. Scholbrock, M. Hofsas, A. Wright, and P. W. Cheng: Proc. The Science of Making Torque from Wind 2012 (2014) p. 012090.

9) 川端浩和, 菊島 義弘, 小垣哲也: 風力エネルギー利用シ ンポジウム 37 (2015) 287.

10) F. Koyama and K. Iga: J. Lightwave Technol. 6 (1988) 87.

11) T. M. Shen and Govind P. Agrawal: J. Lightwave Technol. LT-4 (1986) 497.

12) L. Gillner: Proc.-J IEE. 139 (1992) p. 331

13) E. Udvary and T. Berceli: Proc. European Microwave Association 3 (2007) 217.

14) T. Ando, S. Kameyama, H. Sakai, T. Wakayama, and Y. Hirano: Proc. 13th Coherent Laser Radar Conference (2005) p. 66. 